\begin{tabular}{|c|c|c|c|c|}
\hline JURNAL & \multirow{2}{*}{ VOLUME 3} & \multirow{2}{*}{ NOMOR 1 } & HALAMAN 86-92 & $\begin{array}{l}\text { ISSN 2655-8823 }(p) \\
\text { ISSN 2656-1786 }(e)\end{array}$ \\
\hline KOLABORASI RESOLUSI KONFLIK
\end{tabular}

\title{
ANALISIS KONFLIK SENGKETA LAHAN DI KAWASAN KELURAHAN TAMANSARI KOTA BANDUNG MENGGUNAKAN POHON KONFLIK
}

\author{
Tella Fahira \\ Prodi Ilmu Kesejahteraan Sosial FISIP Universitas Padjajaran \\ E-mail: tellafahira@gmail.com \\ Muhammad Fedryansyah \\ Departemen Kesejahteraan Sosial FISIP Universitas Padjajaran \\ E-mail: m.fedryansyah@unpad.ac.id
}

\begin{abstract}
ABSTRAK
Dalam proses penertiban wilayah kumuh di Indonesia selalu saja berujung pada konflik sosial. konflik ini dilatarbelakangi adanya sengketa lahan antara masyarakat yang tinggal di wilayah kumuh dengan pemerintah. Salah satu wilayah yang mengalami konflik dalam proses penertiban wilayah kumuh adalah wilayah Tamansari di Kota Bandung. Konflik ini terjadi dikarenakan adanya ketidaksepahaman antara masyarakat dan pemerintah dalam rencana pembangunan program rumah deret dan proses pelaksanaannya. Metode penulisan kajian ini adalah dengan menggunakan metode studi literature. Dalam kajian ini akan dijelaskan mengenai analisis konflik yang terjadi di Tamansari dengan menggunakan alat bantu pohon konflik guna mencari pokok permasalahan konflik, penyebab, dan akibat dari konflik yang terjadi serta upaya penyelesaian konflik dengan menggunakan alat bantu roda.
\end{abstract}

Kata kunci: konflik, sengketa lahan, alat bantu pohon konflik.

\section{PENDAHULUAN}

Kota Bandung merupakan salah satu kota besar di Indonesia dan merupakan ibu kota dari Provinsi Jawa Barat. Kota Bandung dapat dikatakan sebagai kota tujuan utama wisata yang memiliki banyak faktor penarik bagi wisatawan yang merupakan potensi yang dimiliki Kota Bandung. Banyaknya tempat-tempat bersejarah di Kota Bandung menjadikan Bandung sebagai tempat wisata heritage seperti pada ruas jalan Asia Afrika-BragaCikapundung. Selain itu kota Bandung juga dijadikan sebagai salah satu ewq6tvtujuan melanjutkan pendidikan karena banyaknya perguruan tinggi ternama di Kota Bandung seperti ITB, UNPAD, UNPAR, UNISBA dll. Namun dengan banyaknya keindahan di kota Bandung, ternyata masih banyak wilayah dan permukiman kumuh, menurut data dari Dinas Perumahan dan Kawasan Permukimanm, Pertanahan dan Pertamanan Kota Bandung pada tahun
2018 tercatat ada sekitar 121 titik kawasan permukiman kumuh di Kota Bandung.

Pemerintah Kota Bandung berencana untuk menertibkan kawasan kumuh yang ada ditengah kota bandung dengan program KOTAKU atau Kota Tanpa Kumuh, program ini sudah dimulai sejak tahun 2017. Salah satu lokasi pemukiman yang dijadikan penerapan program KOTAKU adalah kawasan Tamansari lebih tepatnya pada rw 11kelurahan Tamansari. Penertiban akan dilakukan terhadap bangunan-bangunan di kawasan rumah deret tamansari yang ditinggali sekitar 176 keluarga (Bunga \& Sugiharto, 2019). Program pemerintah dalam melaksanakan program KOTAKU ini ternyata mendapat penolakan dari warga yang enggan untuk direlokasi.

Alih guna lahan kerap kali menyisakan permasalahan yang cukup pelik. Maksud ingin memberikan hunian yang lebih layak untuk warganya seringkali tidak tersampaikan dan terlaksanakan dengan baik. Banyak proses yang terlewati dan 


\begin{tabular}{|c|c|c|c|c|}
\hline JURNAL & \multirow{2}{*}{ VOLUME 3} & \multirow{2}{*}{ NOMOR 1 } & HALAMAN 86-92 & $\begin{array}{l}\text { ISSN 2655-8823 }(p) \\
\text { ISSN 2656-1786 }(e)\end{array}$ \\
KOLABORASI RESOLUSI KONFLIK & HAM \\
\hline
\end{tabular}

konflik sosial pun tak dapat terhindarkan, penolakan dari masyarakat juga marak disuarakan. Menurut Pasal 1 butir 1 UU No. 7 Tahun 2012 tentang Penanganan Konflik Sosial, dijelaskan bahwa yang dimaksud dengan konflik sosial yaitu perseteruan dan/atau benturan fisik dengan kekerasan antara dua kelompok masyarakat atau lebih yang berlangsung dalam waktu tertentu dan berdampak luas yang mengakibatkan ketidaknyamanan dan disintegrasi sosial sehingga mengganggu stabilitas nasional dan menghambat pembangunan nasional.

Pemerintah Kota Bandung pada bulan Juni 2017 mengundang warga Tamansari ke Rumah Dinas Walikota Bandung untuk mensosialisasikan pembangunan rumah deret sebagai solusi dari penataan kawasan kumuh di Kota Bandung, pada saat itu walikota yang masih menjabat adalah Ridwan Kamil yang mengatakan bahwa program rumah deret merupakan program penataan pemukiman tanpa penggusuran. Namun pada faktanya, program ini dinilai oleh sebagian warga sebagai penggusuran gaya baru. Proses sosialisasi yang dilakukan oleh pemerintah menimbulkan kejanggalan terutama pada proses kejelasan ganti rugi lahan, relokasi sementara dan pasca pembangunan selesai (Ar-Ridho \& Ishartono, 2019).

Selain itu terdapat perbedaan terkait penggusuran yang berkaitan dengan kepemilikan tanah. Pemerintah kota Bandung beranggapan lahan yang ditempati warga merupakan milik pemerintah sejak tahun 1933 yang merupakan warisan pemerintah Belanda. Sedangkan warga Tamansari memiliki sense of belonging terhadap lahan yang mereka tempati karena mereka telah menempati lahan tersebut lebih dari puluhan tahun. Hal yang menjadi protes warga adalah bahwa pemerintah menyamaratakan perlakuan tanah yang sudah bersertifikat dan yang belum selesai proses sertifikasinya. Hal inilah yang menjadi permasalahan sengketa lahan antara warga Tamansari dengan pemerintah Kota Bandung. Tulisan ini akan membahas konflik sengketa lahan antara warga Tamansari dengan Pemerintah Kota Bandung dengan menggunakan alat bantu pohon konflik, yakni mencari batang atau inti dari konflik yang terjadi, akar yakni penyebab dari konflik yang terjadi dan cabang atau akibat/ dampak dari konflik yang terjadi.

\section{Pemahaman Mengenai Konflik}

Konflik adalah hubungan natara dua pihak atau lebih (individu atau kelompok) yang memiliki atau yang merasa memiliki, sasaran-sasaran yang tidak sejalan. Konflik berbeda dengan kekerasan. Kekerasan meliputi tindakan, perkataan, sikap dan berbagai struktur atau sistem yang menyebabkan kerusakan secara fisik, mental sosial dan lingkungan. Konflik akan terjadi ketika tujuan masyarakat tidak sejalan. Konflik timbul karena ketidakseimbangan antara hubunganhubungan itu, seperti kesenjangan status sosial, kurang meratanya kemakmuran serta kekuasaan yang tidak seimbang yang kemudian menimbulkan masalah-masalah seperti diskriminasi, penindasan, pengangguran, kejahatan dan lainnya (Widapratama \& Darwis, 2019).

Lebih lanjut, pemahaman konflik dapat dilihat dari jenis-jenis konflik. Adapun jenis-jenis konflik yang sering terjadi menurut (Fisher, Ludin, Williams, Abdi, Smith, \& Williams, 2001) yaitu:

1. Konflik laten, sifatnya tersembunyi dan perlu diangkat ke permukaan sehingga dapat ditangani secara efektif.

2. Konflik manifest, sifatnya terbuka yang berakar dalam dan sangat nyata serta perlu berbagai tindakan untuk mengatasi akar penyebab dan berbagai efeknya.

3. Konflik di permukaan, terjadi karena kesalahpahaman dan dapat diatasi dengan meningkatkan komunikasi. 


\begin{tabular}{|c|c|c|c|c|}
\hline JURNAL & \multirow{2}{*}{ VOLUME 3} & \multirow{2}{*}{ NOMOR 1 } & HALAMAN 86-92 & $\begin{array}{l}\text { ISSN 2655-8823 }(p) \\
\text { ISSN 2656-1786 }(e)\end{array}$ \\
KOLABORASI RESOLUSI KONFLIK & HAM \\
\hline
\end{tabular}

\section{Teori-teori mengenai berbagai penyebab konflik}

(Fisher, Ludin, Williams, Abdi, Smith, \& Williams, 2001) membuat kategorisasi penyebab konflik berdasarkan teori yang mendasarinya sebagai berikut:

a. Teori Hubungan Masyarakat Konflik disebabkan oleh polarisasi yang terus terjadi. Adanya ketidakpercayaan dan permusuhan diantara kelompok yang berbeda dalam suatu masyarakat.

b. Teori Negosiasi Prinsip

Konflik disebabkan oleh posisiposisi yang tidak selaras dan perbedaan pandangan tentang konflik oleh pihak-pihak yang mengalami konflik.

c. Teori Kebutuhan Manusia

Konflik yang berakar dalam disebabkan oleh kebutuhan dasar manusia baik fisik, mental dan sosial yang tidak terpenuhi. Inti pembicaraannya adalah tentang keamanan, identitas, pengakuan, partisipasi dan otonomi.

d. Teori Identitas

Konflik disebabkan karena identitas yang terancam, sering berakar pada hilangnya sesuatu atau penderitaan di masa lalu yang tidak diselesaikan.

e. Teori Kesalahpahaman Antar Budaya

Konflik disebabkan karena ketidakcocokan dalam cara-cara berkomunikasi antar budaya yang berbeda.

f. Teori Transformasi

Konflik Konflik disebabkan oleh masalah-masalah ketidakadilan, ketidaksetaraan yang muncul sebagai masalah sosial, budaya dan ekonomi.

\section{Analisis Konflik dan Mengelola Konflik}

Analisis konflik merupakan suatu proses praktis untuk mengkaji dan memahami kenyataan konflik dari berbagai sudut pandang. Selanjutnya pemahaman ini membentuk dasar untuk mengembangkan strategi dan merencanakan tindakan.

Salah satu alat analisis konflik adalah pohon konflik. Pohon konflik merupakan alat analisis konflik dengan gambar sebuah pohon untuk membantu mengurutkan isuisu pokok suatu konflik dengan cara mengindentifikasikan tiga hal yaitu inti suatu masalah, mengetahui sebab-sebab awal terjadinya konflik dan dampak yang muncul sebagai akibat dari konflik yang terjadi. Pohon konflik memiliki tiga bagian, yakni batang, akar dan cabang. Batang pohon menggambarkan masalah utama dari konflik yang terjadi, akar merupakan penyebab masalah utama dapat terjadi, sedangkan cabang pohon merupakan dampak yang disebabkan oleh konflik yang terjadi.

Dalam tindakan praktis, pengelolaan konflik tidak hanya melakukan analisi berdasarkan pengalaman untuk menghasilkan analisis yang sempurna dan objektif. Lebih dari itu proses pengelolaan konflik disini adalah berusaha untuk memahami suatu situasi dan isu - isu yang yang terkait secara mendalam, sehingga pemahaman yang cukup baik ini dapat membantu menentukan apa yang akan dilakukan. Pengelolaan konflik dapat dilakukan dengan menerapkan strategi roda.

Strategi roda merupakan suatu alat bantu dalam mengelola konflik yang tujuannya untuk memperlihatkan saling keterkaitan antara berbagai bidang, tujuan, dan kepentingan yang berbeda. Alat bantu ini bisa digunakan ketika kita berada pada tahap baru mulai proses dalam pengelolaan konflik dan juga pihak - pihak yang berkepentingan

\section{METODE RISET}

Penelitian ini termasuk ke dalam jenis penelitian studi literature. Jenis penelitian studi literature adalah mencari referensi teori yang relevan dengan kasus atau permasalahan yang ditemukan. Dalam melakukan penelitian ilmiah ini, peneliti 


\begin{tabular}{|c|c|c|c|c|}
\hline JURNAL & \multirow{2}{*}{ VOLUME 3} & \multirow{2}{*}{ NOMOR 1 } & HALAMAN 86-92 & $\begin{array}{l}\text { ISSN 2655-8823 }(p) \\
\text { ISSN 2656-1786 }(e)\end{array}$ \\
KOLABORASI RESOLUSI KONFLIK & HAM \\
\hline
\end{tabular}

melakukan teknik penyusunan secara sistematis untuk memudahkan langkahlangkah yang akan diambil. Peneliti melakukan studi literature pada buku-buku yang membahas mengenai konflik, jurnal dan penelitian yang telah dilakukan berkaitan dengan konflik kepentingan lahan.

\section{PEMBAHASAN}

Konflik ini bermula dari pemerintah Kota Bandung yang berencana untuk menertibkan kawasan kumuh yang ada ditengah kota Bandung dengan program KOTAKU di daerah Tamansari. Pada tahun 2017 pemerintah Kota Bandung mengundang warga Tamansari ke rumah dinas Walikota Bandung untuk mensosialisasikan pembangunan rumah deret sebagai solusi dari penataan kawasan kumuh di Kota Bandung.

\section{Analisis Fenomena Konflik}

Tipe konflik yang terjadi pada permasalahan ini adalah konflik permukaam karena koflik ini terjadi atas kesalahpahaaman dan kurangnya komunikasi antara warga tamanasari dan pemerintah Kota Bandung dan konfliknya merupakan konflik vertical karena konflik terjadi antara pemerintah sebagai pemegang kekuasaan dan warga sebagai masyarakat. Kesalahpahaman yang terjadi menyebabkan terjadinya konflik sosial antara masyarakat dengan pemerintah yang berakhir dengan adanya perlawanan baik dari pihak masyarakat dan pemerintah yang berujung dengan tindakan kekerasan.

Fenomena konflik yang terjadi antara masyarakat dan pemerintah di kawasan tamansari dapat dianalisis menggunakan alat bantu pohon konflik. Alat bantu pohon konflik merupakan alat bantu yang digunakan untuk mencari pokok permasalahan yang terjadi serta sebab dan akibat dari konflik yang terjadi.

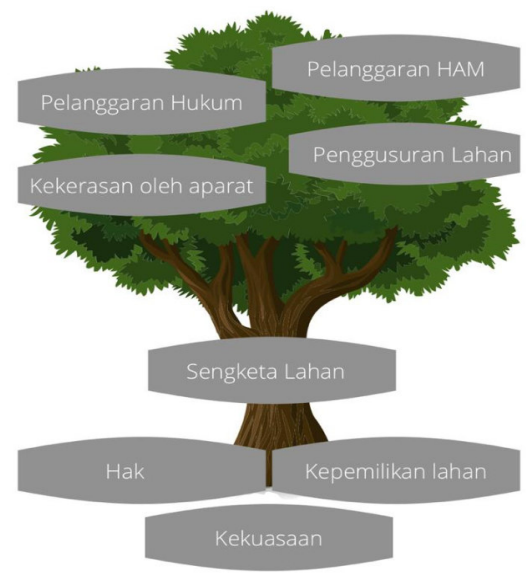

Gambar 1.0 Pohon Konflik

Dari gambar diatas dapat diketahui inti permasalahan dari konflik yang terjadi adalah sengketa lahan antara masyarakat tamansari dan pemerintah Kota Bandung. Penyebab dari konflik yang terjadi yang pertama adalah status kepemilikan lahan menurut kedua belah pihak. Terdapat perbedaan pandangan yang berkaitan dengan status kepemilikan lahan. Pihak pemerintah Kota Bandung beranggapan bahwa lahan yang ditempati oleh warga tamansari merupakan lahan milik pemerintah sejak tahun 1933 yang merupakan warisan dari pemerintah Belanda. Menurut UU pokok agraria, seluruh tanah yang pada awalnya merupakan tanah milik pemrintah Belanda menjadi tanah yang dikuasai Negara.

Sedangkan warga tamansari juga memiliki sense of belonging terhadap lahan yang mereka tempati selama puluhan tahun. Menurut PP No. 24 tahun 1997, seseorang yang menguasasi fisik tanah selama kurun waktu 20 tahun secara terus menerus dapat mendapaftarkan diri sebagai pemegang ha katas tanah yang ditempati. Namun disaat yang sama kedua belah pihak baik warga maupun pemerintah belum dapat menunjukkan sertifikat kepemilikan yang sah.

Penyebab konflik yang kedua adalah adanya kekuasaan dari pihak pemerintah. Menurut (Fisher, Ludin, Williams, Abdi, Smith, \& Williams, 2001). Bentuk 


\begin{tabular}{|c|c|c|c|c|}
\hline JURNAL & \multirow{2}{*}{ VOLUME 3} & \multirow{2}{*}{ NOMOR 1 } & HALAMAN 86-92 & $\begin{array}{l}\text { ISSN 2655-8823 }(p) \\
\text { ISSN 2656-1786 }(e)\end{array}$ \\
KOLABORASI RESOLUSI KONFLIK & HAM \\
\hline
\end{tabular}

kekuasaan ini didukung oleh peraturan, norma, sumber daya dan mungkin kekuatan lain seperti dapat melibatkan poilisi dan tentara. Pemerintah Kota Bandung dinggap secara sepihak menjalankan program serta mekanisme ganti rugi yang tidak sepadan dengan resiko yang akan diterima warga akibat dari penggusuran. Pada konflik yang terjadi di tamansari bentuk kekuasaannya adalah pemaksaan atau kekuasaan yang keras dengan melibatkan pihak kepolisian dan pihak Satpol PP dalam penertiban penggusuran lahan yang berujung pada tindak kekerasan.

Penyebab konflik yang ketiga adalah bentuk protes masyarakat yang merasa bahwa hak-haknya telah dilanggar, dan berkembang menjadi perlawanan bersenjata. Ada beberapa hak dasar yang hilang setelah dilakukannya penggusuran dan relokasi tempat tinggal. hak-hak dasar yang harus dipenuhi yang mana jika hakhak inti tidak dipenuhi maka hak lainnya akan sulit untuk dinikmati, yaitu:

1. Hak untuk hidup tetap dan juga untuk memperoleh mata pencaharian, ketika warga tamansari direlokasi, mereka belum tentu memperoleh mata pencaharian yang sama dengan yang sebelumnya, mereka harus memulai semuanya dari awal ketika mereka harus pindah ke tempat yang baru sedangkan masalah relokasi dan penggantian.

2. Hak atas perlindungan dan kekerasan, ketika proses penggusuran yang dilakukan oleh pihak satpol pp dan pihak kepolisisan adanya tindak kekerasan yang dilakukan oleh pihak aparat seperti pemukulan dan pengejaran terhadap massa aksi bukan hanya kepada masyarakat tetapi juga terhadap simpatisan konflik tamansari ada sekitar 37 warga dan relawan luka saat penggusuran terjadi.
3. Hak atas kesehatan dan pendidikan, ketika permasalahan relokasi yang masih belum jelas, secara tidak langsung akses terhadap kesehatan dan pendidikan juga terhambat, terutama jika sebagian masyarakat masih belum memiliki tempat tinggal yang baru.

4. Hak bagi wanita dan pria untuk menentukan masa depannya. Para masyarakat tidak dapat menentukan massa depannya sendiri, dimana pihak pemerintah menginginkan tempat hidup yang layak bagi masyarakat tamansari tetapi dengan cara yang tidak dapat diterima.

Akibat dari konflik yang terjadi antara warga dan pemerintah di Tamansari adalah yang pertama adanya dugaan tindakan represif yang dilakukan oleh aparat kepolisian dan satpol PP dimana menurut video yang tersebar pihak kepolisian dan satpol PP melakukan pengejaran terhadap massa serta melakukan pemukulan bertubitubi terhadap massa aksi dimana hal tersebut merupakan bentuk kekerasan yang dilakukan oleh aparat.

Dalam upaya penertiban warga yang menghadang petugas ketika melakukan penggusuran paksa, terlihat Petugas Satpol PP menggunakan upaya paksa dengan melempar batu ke arah warga. Namun, Satpol PP dalam melakukan upaya paksa tersebut tidak sesuai dengan SOP Satpol PP itu sendiri yaitu diatur di dalam Lampiran Permendagri Nomor 54 Tahun 2011 tentang Standar Operasional Prosedur Polisi Pamong Praja angka romawi II nomor 8 poin 4 huruf $\mathrm{c}$.

Akibat dari tindakan represif yang dilakukan oleh aparat tersebut adalah sebanyak 37 warga mengalami luka-luka dan juga beberapa warga mengalami trauma akibat dari penggusuran paksa tersebut (Santoso, 2020). 


\begin{tabular}{|c|c|c|c|c|}
\hline JURNAL & \multirow{2}{*}{ VOLUME 3} & \multirow{2}{*}{ NOMOR 1 } & HALAMAN 86-92 & $\begin{array}{l}\text { ISSN 2655-8823 }(p) \\
\text { ISSN 2656-1786 }(e)\end{array}$ \\
KOLABORASI RESOLUSI KONFLIK & HAM \\
\hline
\end{tabular}

\section{Strategi Mengelola Konflik}

Dengan menggunakan analisis roda, kita dapat menemukan hubungan antara tujuan dan juga beberapa perbedaan tindakan yang dilakukan. Tujuan dari analisi roda ini adalah untuk menemukan keterkaitan dari tindakan-tindakan yang akan dilakukan guna mencapai pemecahan konflik.

Dalam alat ini upaya-upaya yang dapat dilakukan adalah meninjau kembali kebijakan kompensasi tanah terhadap masyarakat yang terkena dampak penggusuran baik ganti rugi berupa uang ataupun berupa lahan. Lalu memberikan pemahaman tentang program pembangunan rumah deret yang akan dilakukan oleh pemerintah Kota Bandung agar masyarakat dapat mengetahui alasan serta manfaat dari rumah deret itu sendiri, dan terakhir memberikan saran atau alternative mata pencaharian bagi masyarakat yang terkena dampak penggusuran. Upaya ini dapat dilakukan agar masalah dari kedua belah pihak dapat terselesaikan. Masyarakat dapat menerima ganti rugi yang sepadan serta pemerintah dapat merealisasikan program yang sudah direncanakan.

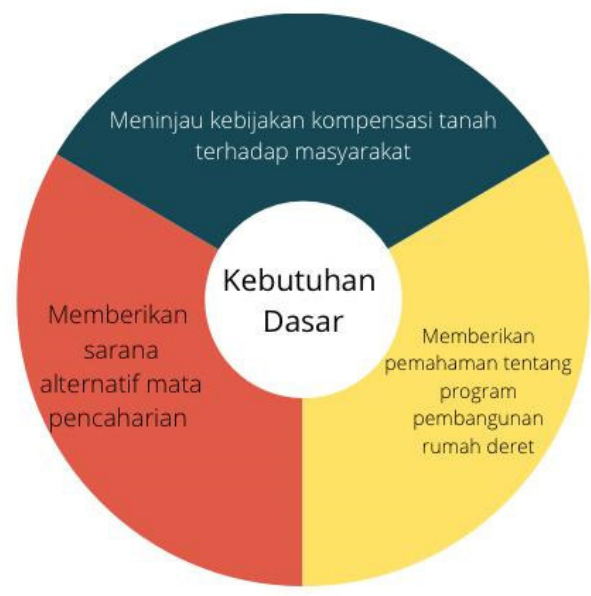

Gambar 2.0

Setelah mencoba untuk menganalisi dan mengelola konflik menggunakan alat bantu, maka kita dapat menentukan isu-isu kritis apa yang menjadi penyebab munculnya konflik tamansari tersebut. Isu kritis yang muncul pada konflik di tamansari adalah isu mengenai hak dan juga kekuasaan.

Dalam konflik tamansari, isu mengenai hak disini dari kedua belah pihak merasa memiliki ha katas lahan yang sedang ditempati. Masyarakat merasa bahwa mereka memiliki ha katas wilayah yang sudah mereka tempati selama puluhan tahun serta pemerintah pun merasa mereka memiliki hak untuk memenglola kawasan kumuh dan membangunnya sebagai bentuk dari pembangunan nasional.

Sedangkan untuk isu mengenai kekuasaan, pemerintah memiliki kekuasaan lebih tinggi dibandingkan masyarakat. pemerintah memiliki otoritas lebih tinggi segingga menjadi keuntungan untuk pihak pemerintah dalam memenangkan kasus ini. Pihak pemerintah mengintervensi kasus ini kedalam jalur hukum dan dimenangkan oleh pihak pemerintah meskipun pihak masyarakat sudah memberikan banding di persidangan.

\section{KESIMPULAN}

Konflik yang terjadi di kawasan kumuh tamansari bersumber dari kebijakan pemerintah yang berencana untuk menertibkan kawasan kumuh di Kota Bandung dengan membangun kawasan rumah deret di daerah Tamansari. Namun pada saat pelaksanaannya ternyata banyak penolakan dari pihak masyarakat diakibatkan oleh proses sosialisasi dan bentuk kompensasi yang dirasa tidak sesuai dengan penggusuran yang dilakukan.

Analisi konflik dilakukan dengan menggunakan alat bantu pohon konflik untuk mengetahui inti permasalahan dari konflik yang terjadi serta penyebab dan akibat dari konflik yang terjadi. Dalam konflik tamansari ditemukan bahwa inti permasalahan dari konflik yang terjadi adalah sengekata tanah antara masyarakat tamansari dan pemerintah Kota Bandung. 


\begin{tabular}{|c|c|c|c|c|}
\hline JURNAL & \multirow{2}{*}{ VOLUME 3} & NOMOR 1 & HALAMAN 86-92 & $\begin{array}{l}\text { ISSN 2655-8823 }(p) \\
\text { ISSN 2656-1786 }(e)\end{array}$ \\
KOLABORASI RESOLUSI KONFLIK
\end{tabular}

Penyebab dari terjadinya konflik adalah status kepemilikan lahan, hak, dan kekuasaan. Dampak dari konflik yang terjadi adalah adanya pelanggaran hukum, pelanggaran HAM, yang berujung terhadap kekerasan yang memberikan dampak trauma terhadap masyarakat tamansari.

Upaya yang dapat dilakukan dengan menggunakan alat bantu roda adalah dengan meninjau kembali kebijakan kompenasasi tanah kepada masyarakat yang terkena dampak serta memberikan alternated mata pencaharian bagi masyarakat terdampak.

\section{DAFTAR PUSTAKA}

Ar-Ridho, A., \& Ishartono. (2019). KONFLIK KEPENTINGAN LAHAN WARGA RW 11 TAMANSARI. Jurnal Kolaborasi Resolusi Konflik Vol.1 Nomor 2 , 70-141.

Bunga, H., \& Sugiharto, J. (2019). Ini Kronolog Penggusuran Tamansari Berujung Kisruh. Tempo.co.

Fisher, S., Ludin, J., Williams, S., Abdi, D. I., Smith, R., \& Williams, S. (2001). Mengelola Konflik. Jakarta: The British Council, Indonesia.

Santoso, B. (2020). Warga Korban Penggusuran Tamansari Bandung Alami Trauma Berat. suarajabar.id.

Widapratama, F. R., \& Darwis, R. S. (2019). PENERAPAN MANAJEMEN KONFLIK. Jurnal Kolaborasi Resolusi Konflik Vol.1 No.1, 1-70. 